\title{
Nuclear Naval Propulsion
}

\author{
Magdi Ragheb \\ Department of Nuclear, Plasma and Radiological Engineering \\ University of Illinois at Urbana-Champaign \\ 216 Talbot Laboratory, Urbana, Illinois
}

USA

\section{Introduction}

The largest experience in operating nuclear power plants has been in nuclear naval propulsion, particularly aircraft carriers and submarines. This accumulated experience may become the basis of a proposed new generation of compact-sized nuclear power plants designs. The mission for nuclear powered submarines is being redefined in terms of signal intelligence gathering and special operations. The nuclear powered vessels comprise about 40 percent of the USA Navy's combatant fleet, including the entire sea based strategic nuclear deterrent. All the USA Navy's operational submarines and over half of its aircraft carriers are nuclear-powered.

The main considerations here are that nuclear powered submarines do not consume oxygen like conventional power plants, and that they have large endurance or mission times before fuel resupply; limited only by the available food and air purification supplies on board. Another unique consideration is the use of High Enriched Uranium (HEU) to provide a compact reactor system with enough built-in reactivity to overcome the xenon reactor dead time for quick restarts and long fuel burnup periods between refuelings.

During World War II, submarines used diesel engines that could be run on the water surface, charging a large bank of electrical batteries. These could later be used while the submarine is submerged, until discharged. At this point the submarine had to resurface to recharge its batteries and become vulnerable to detection by aircraft and surface vessels. Even though special snorkel devices were used to suck and exhaust air to the submarine shallowly submerged below the water's surface, a nuclear reactor provides it with a theoretically infinite submersion time. In addition, the high specific energy, or energy per unit weight of nuclear fuel, eliminates the need for constant refueling by fleets of vulnerable tankers following a fleet of surface or subsurface naval vessels. On the other hand, a single refueling of a nuclear reactor is sufficient for long intervals of time.

With a high enrichment level of 93 percent, capable of reaching 97.3 percent in $U^{235}$, modern naval reactors, are designed for a refueling after 10 or more years over their 20-30 years lifetime, whereas land based reactors use fuel low-enriched to 3-5 percent in U235, and need to be refueled every 1-1 1/2 years period. New cores are designed to last 50 years in carriers and 30-40 years in submarines, which is the design goal of the Virginia class of submarines. Burnable poisons such as gadolinium or boron are incorporated in the cores. These allow a high initial reactivity that compensates for the build-up of fission products poisons over the 
core lifetime, as well as the need to overcome the reactor dead time caused by the xenon poison changes as a result of operation at different power levels.

Naval reactors use high burn up fuels such as uranium-zirconium, uranium-aluminum, and metal ceramic fuels, in contrast to land-based reactors which use uranium dioxide, $\mathrm{UO}_{2}$. These factors provide the naval vessels theoretical infinite range and mission time. For all these considerations, it is recognized that a nuclear reactor is the ideal engine for naval propulsion.

A compact pressure vessel with an internal neutron and gamma ray shield is required by the design while maintaining safety of operation. Their thermal efficiency is lower than the thermal efficiency of land based reactors because of the emphasis on flexible power operation rather than steady state operation, and of space constraints. Reactor powers range from $10 \mathrm{MWth}$ in prototypes to $200 \mathrm{MW}$ th in large subsurface vessels, and $300 \mathrm{MW}$ th in surface ships.

Newer designs use jet pump propulsion instead of propellers, and aim at an all electrical system design, including the weapons systems such as electromagnetic guns.

\section{Historical evolution}

In the USA, initially the General Electric (GE) Company developed a liquid metal reactor concept; and the Westinghouse Company, a pressurized water reactor concept. Each company built an Atomic Energy Commission (AEC) owned and financed development laboratory. Westinghouse used the site of the Allegheny County Airport in a suburb of Pittsburgh, Pennsylvania for what became known as the Bettis Atomic Power Laboratory. GE built the Knolls Atomic Power Laboratory in the state of New York.

The Westinghouse program used pressurized water as the coolant. It revealed how corrosive hot water could be on the metal cladding surrounding the fuel. It realized that the use of zirconium resisted such corrosion. The pure metal was initially used as the cladding for the fuel elements, to be later replaced by a zirconium alloy, Zircaloy that improved its performance. Zirconium has a low neutron absorption cross section and, like stainless steel, forms a protective, invisible oxide film on its surface upon exposure to air. This oxide film is composed of zirconia or $\mathrm{ZrO}_{2}$ and is on the order of only 50 to 100 angstroms in thickness. This ultra thin oxide prevents the reaction of the underlying zirconium metal with virtually any chemical reagent under ambient conditions. The only reagent that will attack zirconium metal at room temperature is hydrofluoric acid, HF, which will dissolve the thin oxide layer off of the surface of the metal and thus allow HF to dissolve the metal itself, with the concurrent evolution of hydrogen gas.

Jules Verne, the French author in his 1870 book: “20,000 Leagues Under the Sea," related the story of an electric submarine. The submarine was called the "Nautilus," under its captain Nemo. Science fiction became reality when the first nuclear submarine built by the USA Navy was given the same name. Construction of the Nautilus (SSN-571) started on June 14, 1952, its first operation was on December 30, 1954 and it reached full power operation on January 13, 1955. It was commissioned in 1954, with its first sea trials in 1955. It set speed, distance and submergence records for submarine operation that were not possible with conventional submarines. It was the first ship to reach the North Pole. It was decommissioned in 1980 after 25 years of service, 2,500 dives, and a travelled distance of 513,000 miles. It is preserved at a museum at Croton, Connecticut, USA. 


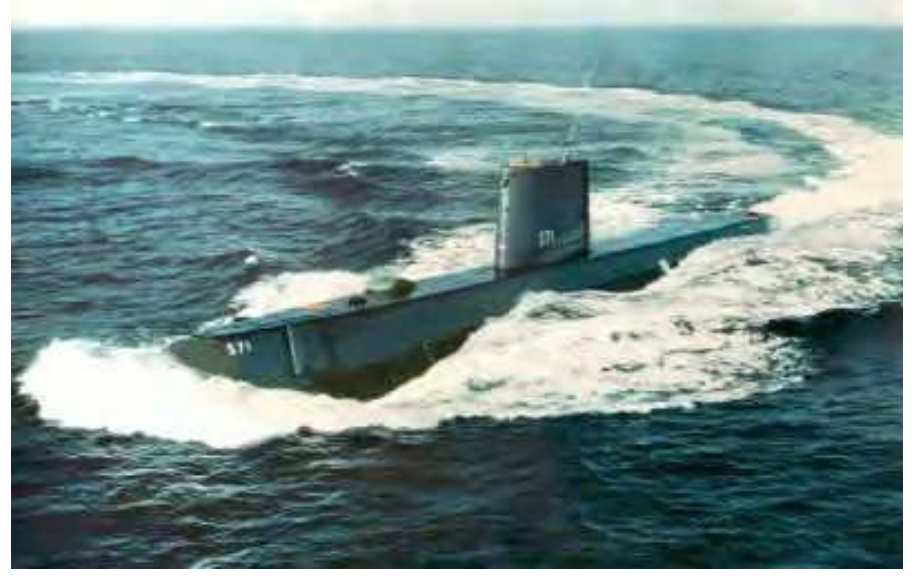

Fig. 1. The "Nautilus", the first nuclear powered submarine (Photo: USA Navy).

An experimental setup designated as the S1W prototype was built for the testing of the Nautilus's nuclear reactor at the Idaho National Laboratory (INL) in 1989. The section of the hull containing the reactor rested in a "sea tank" of water 40 feet deep and 50 feet in diameter. The purpose of the water was to help the shielding designers study the "backscatter radiation" that might escape the hull, scatter off the water, and reflect back into the living quarters of the ship.

The reactor for the Nautilus was a light water moderated, highly enriched in $U^{235}$ core, with zirconium-clad fuel plates. The high fuel enrichment gives the reactor a compact size, and a high reactivity reserve to override the xenon poison dead time. The Nautilus beat numerous records, establishing nuclear propulsion as the ideal driving force for the world's submarine fleet. Among its feats was the first underwater crossing of the Arctic ice cap. It traveled 1,400 miles at an average speed of 20 knots. On a first core without refueling, it traveled 62,000 miles. Another nuclear submarine, the Triton reenacted Magellan's trip around the Earth. Magellan traveled on the surface, while the Triton did it completely submerged.

\section{Reactor design concepts}

There have been more reactor concepts investigated in the naval propulsion area by different manufacturers and laboratories than in the civilian field, and much can be learned from their experience for land applications, particularly for small compact systems. According to the type of vessel they power, they have different first letter designations: A for Aircraft carrier, C for Cruiser, D for Destroyer and S for Submarine. They are also designated with a last letter according to the designer institution or lead laboratory: B for Bechtel, C for Combustion Engineering, G for General Electric and W for Westinghouse. A middle number between the first and last letter refers to the generation number of the core design. For instance, the A1B is the first generation of a core design for aircraft carriers with Bechtel operating the lead laboratory for the design.

Naval reactors designs use boron as a burnable neutron poison. The fuel is an alloy of 15 percent zirconium and 85 percent uranium enriched to a level of about 93 percent in $U^{235}$. The burnable poisons and high enrichment allow a long core lifetime and provide enough 
reactivity to overcome the xenon poisoning reactor dead time. An axial direction doping provides a long core life, and a radial doping provides for an even power and fuel burnup distributions.

\subsection{STR or S1W pressurized water reactor design}

The Westinghouse Electric Corporation under contract to the USA Navy constructed, tested and operated a prototype Pressurized Water Reactor (PWR) submarine reactor plant. This first reactor plant was called the Submarine Thermal Reactor (STR). On March 30, 1953, the STR was brought to power for the first time. In 1953 it achieved a 96 hours sustained full power run simulating a crossing of the Atlantic Ocean. The second S1W core sustained in 1955 an 66-day continuous full power run, simulating a high speed run twice around the globe.

The STR was redesigned as the first generation submarine reactor S1W, which reached criticality on March 30, 1953, was the prototype of the USS Nautilus (SSN 571) reactor and was followed in the middle to late 1950s by the Aircraft carrier reactor A1W, the prototype for the aircraft carrier USS Enterprise plant. Westinghouse's Bettis Atomic Power Laboratory was assigned the responsibility for operating the reactor it had designed and built, hence the $\mathrm{W}$ in the name.

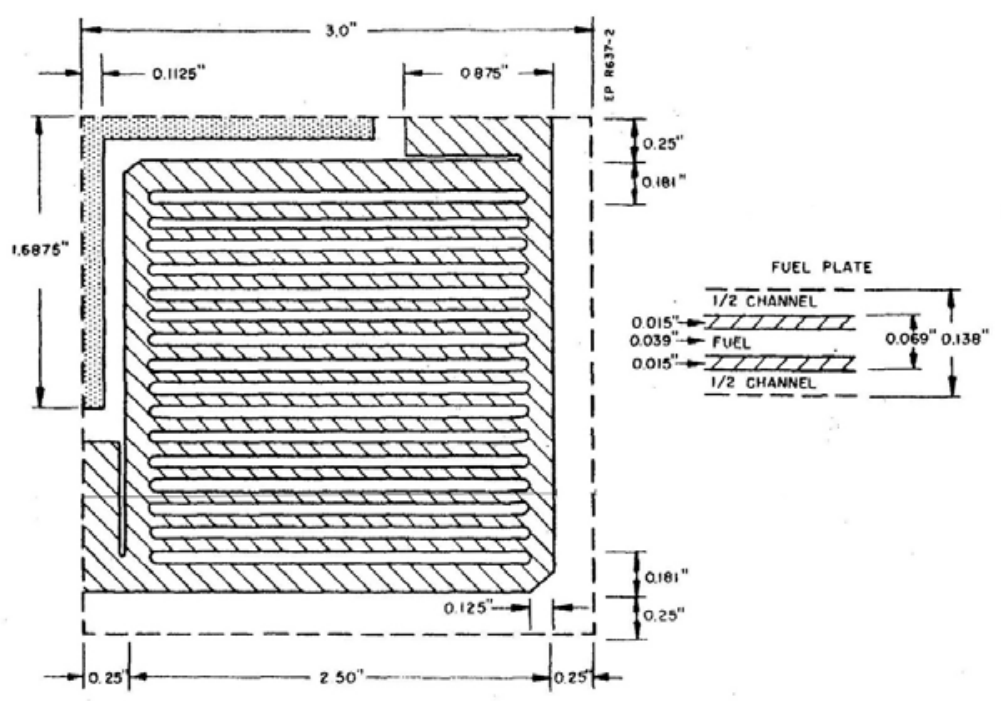

Fig. 2. Plate fuel element configuration (Ragheb, 2011).

The fuel elements are sandwich plates made of $U$ and $\mathrm{Zr}$ and clad in $\mathrm{Zr}$. The maximum temperature in the fuel was $645 \mathrm{oF}$ and the sheath temperature was $551 \mathrm{oF}$ with an average cycle time of 600 hours or just $600 / 24=25$ days. The reactor temperature is limited by the pressure needed to prevent boiling, necessitating high pressure vessels, piping and heat exchangers. The steam was generated at a relatively low pressure. A high level of pumping power was required, and the fuel was costly. However this design presented few hazards, was proven in service, and an expensive moderator was not needed. 
The S1C reactor used an electric drive rather than a steam turbine like in the subsequent S5W reactor design rated at $78 \mathrm{MWth}$ and a 93 percent $\mathrm{U}^{235}$ enriched core that was the standard in the 1970s. The S6G reactor plant was rated at $148 \mathrm{MWth}$ and the D2W core was rated at $165 \mathrm{MWth}$. The S6G reactor is reported to be capable of propelling a Los Angeles class submarine at $15 \mathrm{knots}$ or $27.7 \mathrm{~km} / \mathrm{hr}$ when surfaced and 25 knots or $46.3 \mathrm{~km} / \mathrm{hr}$ while submerged. The Sea Wolf class of submarines was equipped with a single S6W reactor, whereas the Virginia class of submarines is equipped with an S9G reactor.

It is worth noting that the higher achievable submerged speed is partly due to the absence of wave friction resistance underwater, suggesting that submarine cargo ships would offer a future energy saving alternative to surface cargo ships.

\subsection{Large ship reactors, A1W-A, A1W-B prototype plants}

The A1W (Aircraft carrier, 1st prototype, Westinghouse) plant consisted of a pair of prototype reactors for the USS Enterprise USA Navy nuclear-powered aircraft carrier. Located at the Naval Reactors Facility, the two PWRs designated A and B, were built within a portion of a steel hull. The plant simulated the Enterprise's engine room. The A1W plant was the first in which two reactors powered one ship propeller shaft through a singlegeared turbine propulsion unit. As the Navy program evolved, new reactor cores and equipment replaced many of the original components. The Navy trained naval personnel at the A1W plant and continued a test program to improve and further develop its operational flexibility.

The A1W prototype plant was started in 1956 for surface ships using two PWRs. The plant was built as a prototype for the aircraft carrier USS Enterprise (CVN 65), which was the first nuclear-powered aircraft carrier. Power operation of the A1W plant started in October of 1958. In the A1W and A2W designs, the coolant was kept at a temperature between 525-545 ${ }^{\circ} \mathrm{F}$ or $274-285^{\circ} \mathrm{C}$. In the steam generators, the water from the feed system is converted to steam at $535^{\circ} \mathrm{F}$ or $279{ }^{\circ} \mathrm{C}$ and a pressure of about 600 psi or $4 \mathrm{MPa}$. The reactor coolant water was circulated by four large electric pumps for each reactor. The steam was directed from each steam generator to a common header, where the steam is then sent to the main engine, electrical generators, aircraft catapult system, and various auxiliaries. The main propulsion turbines are double ended, in which the steam enters at the center and divides into two opposing streams. The main shaft was coupled to a reduction gear in which the high rotational velocity of the turbine shaft is stepped down to a usable rotational rate for ship propulsion.

In the A3W reactor design used on the USS John F. Kennedy a 4-reactor plant is used. In the A4W design with a life span of 23 years on the Nimitz Class carriers only two reactors per ship are used with each providing 104 MWth of power or 140,000 shaft HP. The A1B is also a two reactor design for the Gerald R. Ford class of carriers.

\subsection{SIR or S1G intermediate neutron flux beryllium sodium cooled reactor}

This reactor design was built by the General Electric (GE) Company, hence the G designation. The neutron spectrum was intermediate in energy. It used $\mathrm{UO}_{2}$ fuel clad in stainless steel with Be used as a moderator and a reflector. The maximum temperature in the fuel could reach $1,700+/-300 \circ \mathrm{F}$ with a maximum sheath temperature of $900 \mathrm{oF}$, with a cycle time of 900 hours or $900 / 24=37.5$ days. 
A disadvantage is that the coolant becomes activated with the heat exchangers requiring heavy shielding. In addition $\mathrm{Na}$ reacts explosively with water and ignites in air, and the fuel element removal is problematic. On the other hand, high reactor and steam temperatures can be reached with a higher thermal efficiency. A low pressure is used in the primary system.

Beryllium has been used as a moderator in the Sea Wolf Class of submarines reactors. It is a relatively good solid moderator, both from the perspectives of slowing down power and of the moderating ratio, and has a very high thermal conductivity. Pure Be has good corrosion resistance to water up to $500 \mathrm{oF}$, to sodium to $1,000 \mathrm{oF}$, and to air attack to $1,100 \mathrm{oF}$. It has a noted vapor pressure at $1,400 \mathrm{oF}$ and is not considered for use much above 1,200 oF even with an inert gas system. It is expensive to produce and fabricate, has poor ductility and is extremely toxic necessitating measures to prevent inhalation and ingestion of its dust during fabrication.

A considerably small size thermal reactor can be built using beryllium oxide as a moderator. It has the same toxicity as Be, but is less expensive to fabricate. It can be used with a sodium cooled thermal reactor design because $\mathrm{BeO}$ is corrosion resistant to sodium. It has similar nuclear properties to Be, has a very high thermal conductivity as a ceramic, and has a good resistance to thermal shock. It can be used in the presence of air, $\mathrm{Na}$ and $\mathrm{CO}_{2}$. It is volatile in water vapor above $1,800 \mathrm{oF}$. In its dense form, it resists attack by $\mathrm{Na}$ or the $\mathrm{Na}-\mathrm{K}$ alloy eutectic, which remains liquid at room temperature, at a temperature of $1,000 \mathrm{oF}$. BeO can be used as a fuel element material when impregnated with uranium. Low density increases its resistance to shock. A BeO coating can be applied to cut down on the fission products release to the system.

The USS Seawolf submarine initially used a Na-cooled reactor that was replaced in 1959 by a PWR to standardize the fleet, because of superheater bypass problems causing mediocre performance and as a result of a sodium fire. The steam turbines had their blades replaced to use saturated rather than superheated steam. The reactor was housed in a containment vessel designed to contain a sodium fire.

The eighth generation S8G reactor was capable of operating at a significant fraction of full power without reactor coolant pumps. The S8G reactor was designed by General Electric for use on the Ohio Class (SSGN/SSBN-726) submarines. A land based prototype of the reactor plant was built at Knolls Atomic Power Laboratory at Ballston Spa, New York. The prototype was used for testing and crew training throughout the 1980s. In 1994, the core was replaced with a sixth generation S6W Westinghouse reactor, designed for the Sea Wolf Class submarines.

\subsection{Experimental Beryllium Oxide Reactor, EBOR}

The Experimental Beryllium Oxide Reactor (EBOR)'s objective was to develop beryllium oxide as a neutron moderator in high-temperature, gas-cooled reactors. The project was cancelled in 1966 before construction was complete. Among the reasons for the cancellation was the encouraging progress achieved, concurrent with the EBOR construction, in developing graphite as a moderator. This reduced the importance of developing beryllium oxide as an alternate. No uranium fuel ever was loaded into the EBOR and it never operated or went critical before the program was cancelled.

\subsection{SC-WR super critical water reactor}

The Super Critical Water Reactor (SC-WR) was considered with an intermediate energy neutron spectrum. The fuel was composed of $\mathrm{UO}_{2}$ dispersed in a stainless steel matrix. It 
consisted of 1 inch square box with parallel plates and sine wave filters with a type 347 stainless steel cladding 0.007 inch thick. The maximum temperature in the fuel reached 1,300 oF with an average cycle time of 144 hours or 144 / $24=6$ days.

The materials for high pressure and temperature and the retention of mechanical seals and other components caused a service problem. The water coolant reached a pressure of 5,000 psi. The high pressure and temperature steam results in a high cycle efficiency, small size of the reactor with no phase change in the coolant.

\subsection{Organic Moderated Reactor Experiment, OMRE}

The Organic Cooled and Moderated Reactor has been considered as a thermal neutron spectrum shipboard power plant. The Terphenyl waxy organic coolant was considered promising because it liquefied at high temperatures but did not corrode metals like water. Also, it operated at low pressure, significantly reducing the risk of coolant leak and loss of coolant through depressurization. A scaled-up reactor, the Experimental Organic Cooled Reactor, was built in anticipation of further development of the concept.

The rectangular-plates fuel clad in aluminum can be natural uranium since the organic coolant can have good moderating properties. The cladding temperature can reach $800 \mathrm{oF}$ with an average cycle time of 2,160 hours or 2,160 / 24 = 90 days. The overall heat transfer coefficient of the coolant is low with the formation of polymers under irradiation that require an adequate purification system. The perceived advantages are negligible corrosion and the achievement of low pressure at a high temperature.

A Diphenyl potential coolant broke down under irradiation. The hydrogen in the compound turned into a gas, forming bubbles. The bubbles reduced the moderator density and made it difficult to maintain the chain reaction. The initially clear liquid turned into a gummy and black breakup product. No uranium fuel ever was loaded into the reactor and it never operated or went critical before the program was cancelled.

\subsection{Lead-bismuth cooled fast reactors}

The alpha class of Russian submarines used an alloy of $\mathrm{Pb}-\mathrm{Bi} 45-50$ percent by weight cooled fast reactors. The melting point of this alloy is $257 \mathrm{oF}$. They faced problems of corrosion of the reactor components, melting point, pump power, polonium activity and problems in fuel unloading. Refueling needed a steam supply to keep the liquid metal molten. Bismuth leads to radiation from the activated products, particularly polonium. An advantage is that at decommissioning time, the core can be allowed to cool into a solid mass with the lead providing adequate radiation shielding. This class of submarine reactors has been decommissioned.

\subsection{Natural circulation S5G prototype}

The S5G was the prototype of a PWR for the USS Narwhal. It was capable of operating in either a forced or natural circulation flow mode. In the natural circulation mode, the cooling water flowed through the reactor by natural convection, not by pumps. Use of natural circulation instead of pumps reduced the noise level in the submarine. To prove that the design concept would work in an operating ship at sea, the prototype was built in a submarine hull section capable of simulating the rolling motion of a ship at sea. The S5G continued to operate as part of the Navy's nuclear training program until that program was reduced after the end of the Cold War. 
The S5G reactor had two coolant loops and two steam generators. It had to be designed with the reactor vessel situated low in the ship hull and the steam generators high in order for natural circulation of the coolant to be developed and maintained using the chimney effect. It was largely a success, although the design never became the basis for any more fast attack submarines besides the Narwhal. The prototype testing included the simulation of the engine room of an attack submarine. By floating the plant in a large pool of water, the whole prototype could be rotated along its long axis to simulate a hard turn. This was necessary to determine whether natural circulation would continue even during hard maneuvers, since natural circulation is dependent on gravity.

The USS Narwhal had the quietest reactor plant in the USA naval fleet. Its $90 \mathrm{MWth}$ reactor plant was slightly more powerful than the other fast attack USA nuclear submarines of that era such as the third generation S3G and the fifth generation S5W. The Narwhal contributed significantly to the USA effort during the Cold War. With its quiet propulsion and the pod attached to its hull, it used a towed sonar array and possibly carried a Remotely Operated Vehicle (ROV) for tapping into communication cables and maintaining a megaphones tracking system at the bottom of the oceans.

It was intended to test the potential contribution of natural circulation technology to submarine noise suppression by the avoidance of forced flow pump cooling. The reactor primary coolant pumps are one of the primary sources of noise from submarines in addition to the speed reduction gearbox and cavitation forming collapsing bubbles from the propeller. The elimination of the coolant pumps and associated equipment would also reduce mechanical complexity and the space required by the propulsion equipment. The S5G was the direct precursor to the eighth generation S8G reactor used on the Ohio class ballistic missile submarines; a quiet submarine design.

The S5G was also equipped with coolant pumps that were only needed in emergencies to attain high power and speed. The reactor core was designed with very smooth paths for the coolant. Accordingly, the coolant pumps were smaller and quieter than the ones used by the competing S5W core, a Westinghouse design, and were also fewer in number. In most situations, the submarine could be operated without using the coolant pumps, useful for stealth operation. The reduction in the electrical requirements enabled this design to use only a single electrical turbine generator plant.

The S8G prototype used natural circulation allowing operation at a significant fraction of full power without using the reactor pumps, providing a silent stealth operation mode. To further reduce engine plant noise, the normal propulsion setup of two steam turbines driving the propeller screw through a reduction gear unit was changed instead to one large propulsion turbine without reduction gears. This eliminated the noise from the main reduction gears, but at the expense of a large main propulsion turbine. The turbine was cylindrical, about 12 feet in diameter and 30 feet in length. This large size was necessary to allow it to rotate slowly enough to directly drive the propulsion screw and be fairly efficient in the process.

\subsection{Fail-safe control and load-following S7G design}

The S7G core was controlled by stationary gadolinium-clad tubes that were partially filled with water. Water was pumped from the portion of the tube inside the core to a reservoir above the core, or allowed to flow back down into the tube. A higher water level in the tube within the core slowed down the neutrons allowing them to be captured by the gadolinium tube cladding rather than the uranium fuel, leading to a lower power level. 
The design constituted a unique fail-safe control system. The pump needed to run continuously to keep the water level pumped down. Upon an accidental loss of pump power, all the water would flow back into the tube, shutting down the reactor.

This design also had the advantage of a negative reactivity feedback and a load-following mechanism. An increase in reactor power caused the water to expand to a lower density lowering the power. The water level in the tubes controlled the average coolant temperature, not the reactor power. An increase in steam demand resulting from opening the main steam throttle valves would automatically increase reactor power without action by the operator.

\subsection{S9G high energy density core}

The S9G is a PWR built by General Electric with increased energy density, and new plant components, including a new steam generator design featuring improved corrosion resistance and a reduced life cycle cost. This reactor in the Virginia Class SSN-774 submarines is designed to operate for 33 years without refueling and last the expected 30 year design life of a typical submarine. It produces about 40,000 shaft horsepower, or about $30 \mathrm{MW}$ th of power.

The higher power density decreases not only the size of the core, but also enhances quiet operation through the elimination of bulky control and pumping equipment. It would be superior to any Russian design from the perspective of noise reduction capability, with 30 units planned to be built. The core for a contemplated New Attack Submarine is expected to last for the operational life of the ship. The design goals include eliminating the need for a refueling, will reduce life cycle costs, cut down the radiation exposure of shipyard staff, and lessen the amount of radioactive waste generated. This is possible because of many developments such as the use of advanced computers to perform three-dimensional nuclear, thermal, and structural calculations; further exploitation of a modified fuel process; and better understanding of various reactor technologies which permits more highly optimized designs. Performance improvements are gained through advances in such areas as thermal hydraulics and structural mechanics, and by optimizing reactor-to-systems interfaces.

The new reactor with increased energy density has new plant components, such as a new concept steam generator, with improved corrosion resistance and reduced life-cycle costs. The new steam generators allow greater plant design flexibility and decreased construction costs due to a smaller size, spatial orientation, and improved heat transfer efficiency which reduces coolant flow requirements. They alleviate the corrosion concerns encountered in existing designs of steam generators, while reducing component size and weight and providing greater flexibility in the overall arrangement.

\section{Commercial nuclear ships}

The USA built one single nuclear merchant ship: the Savannah. It was designed as a national showpiece, and not as an economical merchant vessel. For compactness, the steam generators and steam drums surround the reactor core. This Integral Design configuration also provides shielding for the crew. It was retired in 1970.

The 630-A reactor, a low-power critical experiment, was operated at the Idaho National Laboratory (INL) to explore the feasibility of an air-cooled, water-moderated system for nuclear-powered merchant ships. Further development was discontinued in December 1964 when decisions were made to lower the priority of the entire nuclear power merchant ship program. 
Nuclear Ice Breakers like the Russian Lenin and the Arktica were a good success, not requiring refueling in the arctic regions. The Otto Hahn bulk ore carrier was built by Germany. It operated successfully for ten years. The Mutsu was an oceanographic research vessel built in Japan in 1974. Due to a design flaw causing a radiation leakage from its top radiation shield, it never became fully operational. The Sturgis $\mathrm{MH}-1 \mathrm{~A}$ was a floating nuclear power plant ship. It was carrying a 45 Megawatts Thermal (MWth) PWR providing remote power supplies for the USA Army.

\begin{tabular}{|c|c|c|}
\hline \multirow{2}{*}{ Reactor type } & \multicolumn{2}{|c|}{ Rated power } \\
\cline { 2 - 3 } & $\begin{array}{c}\text { shaft horse power, } \\
{[\text { shp] }}\end{array}$ & {$[\mathrm{MW}]^{*}$} \\
\hline A2W & 35,000 & 26.1 \\
\hline A4W/A1G & 140,000 & 104.4 \\
\hline C1W & 40,000 & 29.8 \\
\hline D2G & 35,000 & 26.1 \\
\hline S5W & 15,000 & 11.2 \\
\hline S5G & 17,000 & 12.7 \\
\hline S6W & 35,000 & 26.1 \\
\hline S8G & 35,000 & 26.1 \\
\hline S9G & 40,000 & 29.8 \\
\hline
\end{tabular}

* $1 \mathrm{shp}=745.6999 \mathrm{Watt}=0.7456999 \mathrm{~kW}$

Table 1. Power ratings of naval reactor designs.

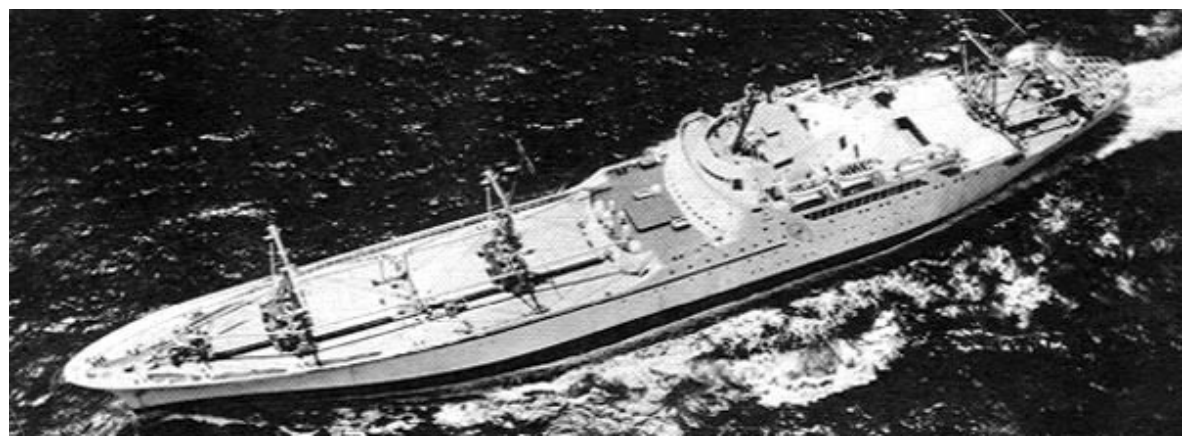

Fig. 3. The Savannah, the first USA merchant ship.

\section{Power plant configurations}

The nuclear navy benefited the civilian nuclear power program in several ways. It first demonstrated the feasibility of the PWR concept, which is being currently used in the majority of land based power reactors worldwide. Second, naval reactors accumulated a large number of operational experience hours, leading to improvements in the land based reactors. The highly trained naval operational crews also become of great value to the civilian nuclear utilities providing them with experienced staffs in the operation and management of the land based systems. 


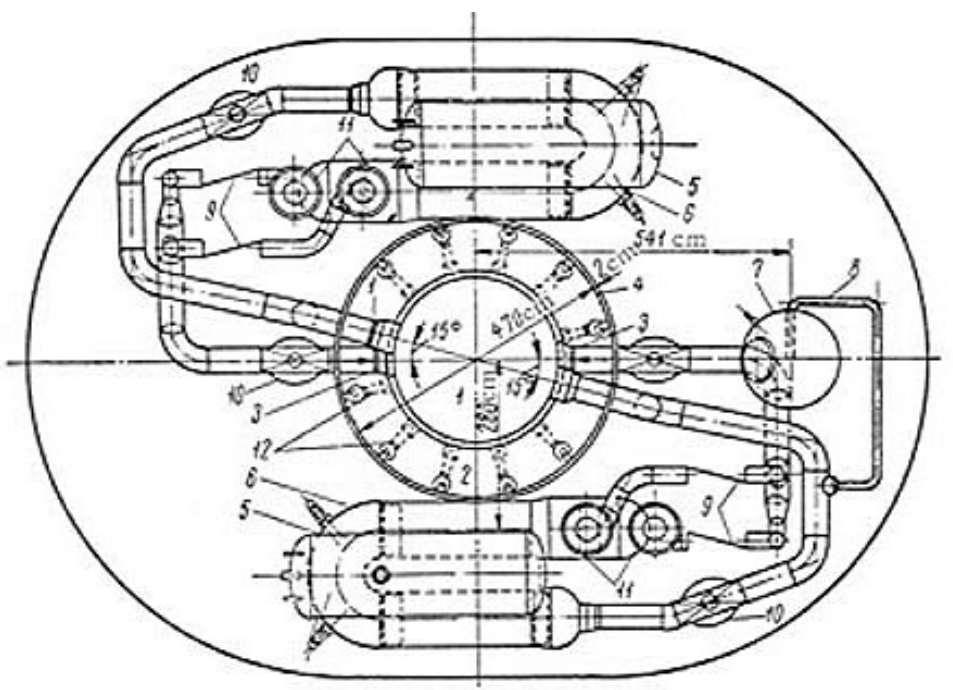

Fig. 4. The loop-type naval reactor design for the nuclear ship Savannah. The reactor core is surrounded by the heat exchangers and the steam drums providing a compact shielding design. The horizontal steam generator was replaced by a vertical tube steam generator and an integrated system in subsequent designs. 1: Reactor core, 2: Water shield, 3: Coolant inlet, 4: Pb Shield layer, 5: Steam drum, 6: Heat exchanger, 7: Pressurizer, or volume compensator, 8: Equalizer line, 9: Cutoff channel, 10: Gate valve, 11: Coolant pumps, 12: Instrumentation channel. (Broder, 1970).

Land based reactors differ in many ways from naval reactors. The thermal power of land based reactors is in the range of 3,000 MWth or higher. In contrast, a submarine reactor's power is smaller in the range of the hundreds of MWths. Land based systems use uranium fuel lightly enriched to the 3-5 percent range. This low level enrichment was imposed on the designers of land-based reactors to primarily avoid the circulation of highly enriched fuel. It is an impediment since it forces the use of a large volume for the core, increases the capital cost and hence the cost of the electricity produced. Highly enriched fuel at the 93-97 percent level is used in naval reactors to provide enough reactivity to override the xenon poison dead time, compactness as well as provide higher fuel burnup and the possibility for a single fuel loading over the useful service time of the powered ship.

Table 2 shows the composition of highly enriched fuel used in nuclear propulsion as well as space reactor designs such as the SAFE-400 and the HOMER-15 designs (Poston, 2002). Most of the activity is caused by the presence of $U 234$, which ends up being separated with the U235 component during the enrichment process. This activity is primarily alpha decay and does not account for any appreciable dose. Since the fuel is highly purified and there is no material such as fluorine or oxygen causing any $(a, n)$ reactions in the fuel, the alpha decay of $U^{234}$ does not cause a neutron or gamma ray dose. If uranium nitride (UN) is used as fuel, the interaction threshold energy of nitrogen is well above the alpha emission energies of $\mathrm{U}^{234}$. Most of the dose prior to operation from the fuel is caused by $\mathrm{U}^{235}$ decay gammas and the spontaneous fission of $U^{238}$. The total exposure rate is 19.9 [ $\mu$ Röntgen / hr] of which the gamma dose rate contribution is 15.8 and the neutron dose rate is 4.1. 


\begin{tabular}{|c|c|c|c|c|}
\hline Isotope & $\begin{array}{c}\text { Composition } \\
\text { (percent) }\end{array}$ & $\begin{array}{c}\text { Activity } \\
\text { (Curies) }\end{array}$ & $\begin{array}{c}\text { Decay } \\
\text { Mode }\end{array}$ & $\begin{array}{c}\text { Exposure Rate } \\
\text { Contribution } \\
{[\mu \mathrm{R} / \mathrm{hr}]}\end{array}$ \\
\hline $\mathrm{U}^{234}$ & 0.74 & 6.1 & Alpha decay & unappreciable \\
\hline $\mathrm{U}^{235}$ & 97.00 & & Decay gammas & appreciable \\
\hline $\mathrm{U}^{238}$ & 2.259 & & $\begin{array}{c}\text { Spontaneous } \\
\text { fissions }\end{array}$ & appreciable \\
\hline $\mathrm{Pu}^{239}$ & 0.001 & & Alpha decay & unappreciable \\
\hline Total & & 6.5 & & 19.9 \\
\hline
\end{tabular}

Table 2. Composition of highly enriched fuel for naval and space reactors designs (Poston, 2002).

Reactor operators can wait for a 24 hours period; the reactor dead time, on a land based system for the xenon fission product to decay to a level where they can restart the reactor. A submarine cannot afford to stay dead in the water for a 24 hour period if the reactor is shutdown, necessitating highly enriched fuel to provide enough high reactivity to overcome the reactor dead time effect. A nuclear submarine has the benefit of the ocean as a heat sink, whereas a land based reactor needs sufficiently large water reservoirs to be available for its safety cooling circuits

For these reasons, even though the same principle of operation is used for naval and land based reactor designs, the actual designs differ substantially. Earlier naval reactors used the loop type circuit for the reactor design for the Savannah reactor. There exists a multitude of naval reactor designs. More modern designs use the Integral circuit type.

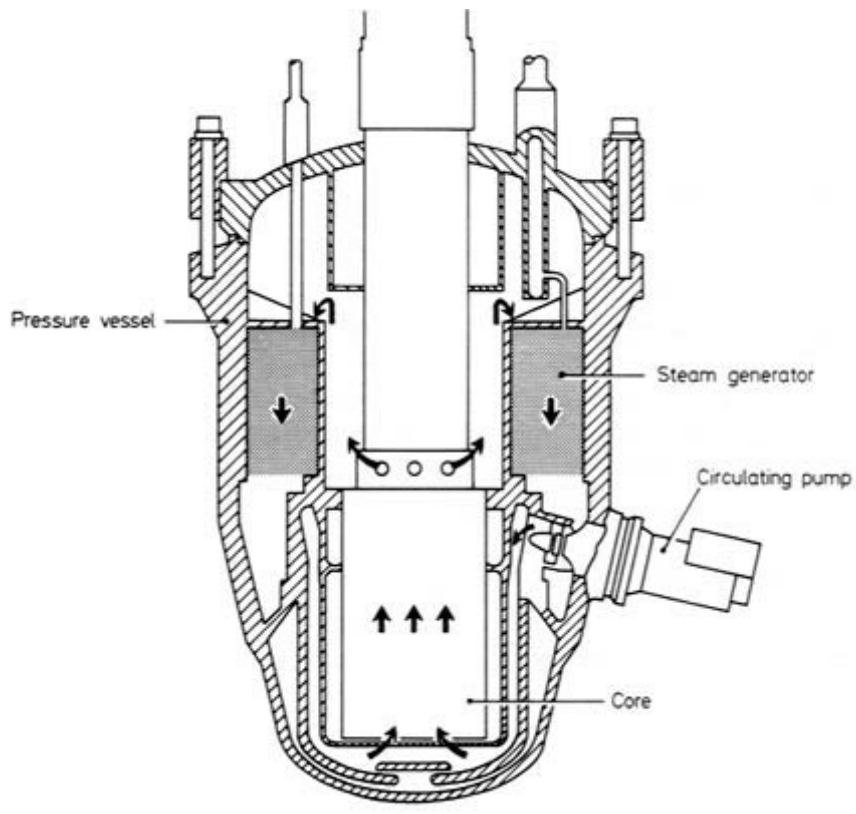

Fig. 5. Integral type of naval reactor vessel (Collier, 1987). 
Because of the weight of the power plant and shielding, the reactor and associated steam generation equipment is located at the center of the ship. Watertight bulkheads isolating the reactor components surround it. The greater part of the system is housed in a steel containment, preventing any leakage of steam to the atmosphere in case of an accident. The containment vessel for the Savannah design consisted of a horizontal cylindrical section of 10.7 meters diameter, and two hemispherical covers. The height of the containment was 15.2 meters. The control rod drives are situated in a cupola of $4.27 \mathrm{~m}$ in diameter, on top of the containment. The containment vessel can withstand a pressure of $13 \mathrm{~atm}$. This is the pressure attained in the hypothetical maximum credible accident, or design-basis accident. It is postulated as the rupture of the primary loop and the subsequent flashing into steam of the entire coolant volume.

The secondary shielding consists of concrete, lead, and polyethylene and is positioned at the top of the containment. A prestressed concrete wall with a thickness of $122 \mathrm{~cm}$ surrounds the lower section of the containment. This wall rests on a steel cushion. The upper section of the secondary shielding is $15.2 \mathrm{~cm}$ of lead to absorb gamma radiation, and $15.2 \mathrm{~cm}$ of polyethylene to slow down any leaking neutrons. The space between the lead plates is filled with lead wool. The lead used in the shielding is cast by a special method preventing the formation of voids and inhomogeneities.

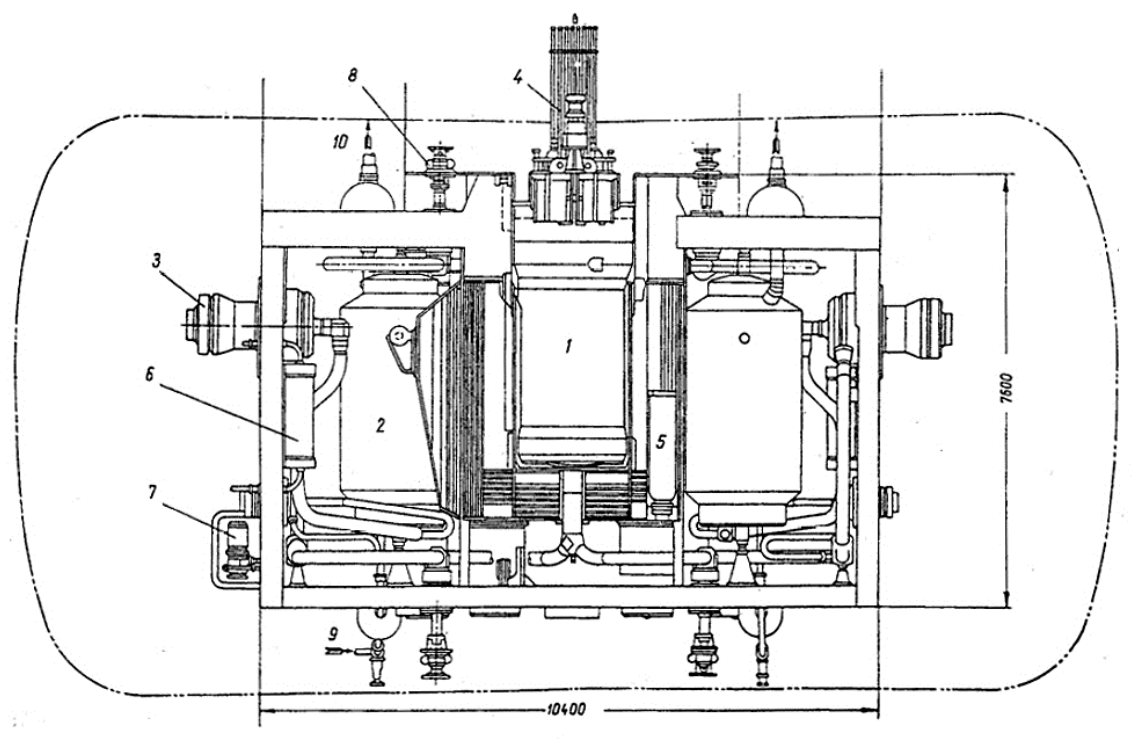

Fig. 6. Layout of the OK-150 plant. 1: Reactor, 2: Steam generator, 3: Main circulation pumps, 4: Control rod drives mechanism, 5: Filter, 6: Cooler, 7: Emergency cooling pump, 8: Primary circuit pressure relief valve, 9: Feedwater inlet, 10: Steam outlet (Reistad et. al., 2006).

The polyethylene sheets are spaced so as to allow thermal expansion. Thick collison mats consisting of alternate layers of steel and wood are placed on the sides of the containment. The effective dose rate at the surface of the secondary sheet does not exceed $5 \mathrm{cSv}$ (rem)/year. The containment is airtight. Personnel can remain in it for up to 30 minutes after reactor shutdown and the radiation level would have fallen to less than $0.2 \mathrm{cSv}(\mathrm{rem}) / \mathrm{hr}$. 
The primary shielding is here made of an annular water tank that surrounds the reactor and a layer of lead attached to the outer surface of the tank, to minimize space. The height of the tank is $5.2 \mathrm{~m}$, the thickness of the water layer, $84 \mathrm{~cm}$, and the thickness of the lead is $5-10 \mathrm{~cm}$. The weight of the primary shields is 68.2 tons, and with the water it is 118.2 tons. The weight of the containment is 227 tons. The secondary shielding weights 1795 tons consisting of: 561 tons of ordinary concrete, 289 tons of lead, 69 tons of polyethylene, and 160 tons of collison mats. The latter consist of 22 tons of wood and 138 tons of steel. The shielding complex is optimized to minimize the space used, while providing low radiation doses to the crew quarters. It is comparatively heavy because of the use of lead and steel, and is complicated to install.

The Integral circuit design offers a substantial degree of inherent safety since the pumps; the steam generators and reactor core are all contained within the same pressure vessel. Since the primary circulating fluid is contained within the vessel, any leaking fluid would be contained within the vessel in case of an accident. This also eliminates the need for extensive piping to circulate the coolant from the core to the steam generators. In loop type circuits, a possibility exists for pipe rupture or leakage of the primary coolant pipes. This source of accidents is eliminated in an integral type of a reactor (Collier, 1987).

\section{Xenon generation}

The fission process generates a multitude of fission products with different yields (Lamarsh, 1983). Table 3 shows some of these fission products yields resulting from the fission of three fissile isotopes:

\begin{tabular}{|c|c|c|c|}
\hline Isotope & ${ }_{92} \mathrm{U}^{233}$ & ${ }_{92} \mathrm{U}^{235}$ & ${ }_{94} \mathrm{Pu}^{239}$ \\
\hline${ }_{53} \mathrm{I}^{135}$ & 0.04750 & 0.06390 & 0.06040 \\
\hline${ }_{54} \mathrm{Xe}^{135}$ & 0.01070 & 0.00237 & 0.01050 \\
\hline${ }_{61} \mathrm{Pm}^{149}$ & 0.00795 & 0.01071 & 0.01210 \\
\hline
\end{tabular}

Table 3. Fission products yields from thermal $2200 \mathrm{~m} / \mathrm{sec}$ neutrons, $\gamma_{i}$ [nuclei/fission event] (Lamarsh, 1983).

The most prominent of these fission products from the perspective of reactor control is ${ }_{54} \mathrm{Xe}^{135}$. It is formed as the result of the decay of ${ }_{53} \mathrm{I}^{135}$. It is also formed in fission and by the decay of the tellurium isotope: ${ }_{52} \mathrm{Te}^{135}$. This can be visualized as follows:

$$
\begin{aligned}
\text { Fission } & \rightarrow{ }_{52} \mathrm{Te}^{135}+{ }_{53} I^{135}+{ }_{54} \mathrm{X} e^{135} \\
{ }_{52} \mathrm{Te}^{135} & \rightarrow{ }_{53} I^{135}+{ }_{-1} e^{0}+v^{*} \\
{ }_{53} I^{135} & \rightarrow{ }_{54} \mathrm{Xe}^{135}+{ }_{-1} e^{0}+v^{*} \\
{ }_{54} \mathrm{X} e^{135} & \rightarrow{ }_{55} \mathrm{Cs}^{135}+{ }_{-1} e^{0}+v^{*} \\
{ }_{55} \mathrm{Cs}^{135} & \rightarrow{ }_{56} \mathrm{Ba}^{135}(\text { stable })+{ }_{-1} e^{0}+v^{*}
\end{aligned}
$$

The half lives of the components of this chain are shown in Table 4 . The end of the chain is the stable isotope ${ }_{6} \mathrm{Ba}^{135}$. Because ${ }_{52} \mathrm{Te}^{135}$ decays rapidly with a half life of 11 seconds into ${ }_{53} \mathrm{I}^{135}$, one can assume that all ${ }_{53} \mathrm{I}^{135}$ is produced directly in the fission process. 
Denoting I $(\mathrm{t})$ as the atomic density of iodine in [nuclei/ $\left.\mathrm{cm}^{3}\right], \psi$ as the thermal neutron flux $[\mathrm{n} /(\mathrm{cm} 2 . \mathrm{sec})]$ one can write a rate equation for the iodine as:

$$
\begin{aligned}
& \frac{d I(t)}{d t}=[\text { rate of formation of iodine from fission }] \\
& -[\text { rate of radioactive transformations of iodine }] \\
& \frac{d I(t)}{d t}=\gamma_{I} \Sigma_{f} \psi-\lambda_{I} I(t)
\end{aligned}
$$

where: $\quad \gamma_{I}$ is the fission yield in [nuclei/fission event],

$\sum_{\mathrm{f}}$ is the thermal fission cross section in $\left[\mathrm{cm}^{-1}\right]$,

$\lambda_{\mathrm{I}}$ is the decay constant in $\left[\mathrm{sec}^{-1}\right]$, with $\lambda_{\mathrm{I}}=\frac{\ln 2}{\mathrm{~T}_{1 / 2}}, \mathrm{~T}_{1 / 2}$ is the half life.

\begin{tabular}{|c|c|}
\hline Isotope & Half Life, $\mathrm{T}_{1 / 2}$ \\
\hline${ }_{52} \mathrm{Te}^{135}$ & $11 \mathrm{sec}$ \\
\hline${ }_{53} \mathrm{I}^{135}$ & $6.7 \mathrm{hr}$ \\
\hline${ }_{54} \mathrm{Xe}^{135}$ & $9.2 \mathrm{hr}$ \\
\hline${ }_{55} \mathrm{Cs}^{135}$ & $2.3 \times 10^{6} \mathrm{yr}$ \\
\hline${ }_{56} \mathrm{Ba}^{135}$ & Stable \\
\hline
\end{tabular}

Table 4. Half lives of the isotopes in the xenon decay chain.

A rate equation can also be written for the xenon in the form:

$$
\begin{aligned}
& \frac{d X(t)}{d t}=[\text { rate of formation of xenon from fission }] \\
& +[\text { rate of formation of Xe from the transformation of the Iodine }] \\
& -[\text { rate of radioactive transformations of xenon }] \\
& \quad-[\text { rate of disappearance of xenon }(X) \text { through neutron absorptions }], \\
& \text { or: } \\
& \frac{d X(t)}{d t}=\gamma_{X} \Sigma_{f} \psi+\lambda_{I} I(t)-\lambda_{X} X(t)-\sigma_{a X} \psi X(t)
\end{aligned}
$$

where $\sigma_{a X}$ is the thermal microscopic absorption cross section for xenon equal to $2.65 \times 10^{6}$ [b].

The large value of the absorption cross section of $\mathrm{Xe}$, and its delayed generation from iodine, affect the operation of reactors both under equilibrium and after shutdown conditions.

\section{7. lodine and xenon equilibrium concentrations}

Under equilibrium conditions, the rate of change of the iodine as well as the xenon concentrations is zero:

$$
\frac{d I(t)}{d t}=\frac{d X(t)}{d t}=0
$$


This leads to an equilibrium concentration for the iodine as:

$$
I_{0}=\frac{\gamma_{I} \Sigma_{f} \psi}{\lambda_{I}}
$$

The equilibrium concentration for the xenon will be:

$$
X_{0}=\frac{\gamma_{X} \Sigma_{f} \psi+\lambda_{I} I_{0}}{\lambda_{X}+\sigma_{a X} \psi}
$$

Substituting for the equilibrium concentration of the iodine, we can write:

$$
X_{0}=\frac{\left(\gamma_{X}+\gamma_{I}\right) \Sigma_{f} \psi}{\lambda_{X}+\sigma_{a X} \psi}
$$

\section{Reactivity equivalent of xenon poisoning}

Ignoring the effects of neutron leakage, since it has a minor effect on fission product poisoning, we can use the infinite medium multiplication factor for a poisoned reactor in the form of the four factor formula (Ragheb, 1982):

$$
k=\eta \varepsilon p f
$$

and for an unpoisoned core as:

$$
k_{0}=\eta \varepsilon p f_{0}
$$

We define the reactivity $\rho$ of the poisoned core as:

$$
\rho=\frac{k-k_{0}}{k}=\frac{\Delta k}{k}=\frac{f-f_{0}}{f}=1-\frac{f_{0}}{f}
$$

In this equation,

$\eta=\frac{v \Sigma_{f}}{\Sigma_{a F}}$, is the regeneration factor,

$\varepsilon$ is the fast fission factor,

$\mathrm{p}$ is the resonance escape probability,

$v$ is the average neutron yield per fission event,

$\Sigma_{\mathrm{f}}$ is the macroscopic fission cross section,

$\Sigma_{\mathrm{aF}}$ is the macroscopic absorption cross section of the fuel,

$\mathrm{f}$ is the fuel utilization factor.

The fuel utilization factor for the unpoisoned core is given by:

$$
f_{0}=\frac{\Sigma_{a F}}{\Sigma_{a F}+\Sigma_{a M}}
$$

And for the poisoned core it is: 


$$
f=\frac{\Sigma_{a F}}{\Sigma_{a F}+\Sigma_{a M}+\Sigma_{a P}}
$$

where:

$\Sigma_{\mathrm{aM}}$ is the moderator's macroscopic absorption coefficient,

$\Sigma_{\mathrm{aP}}$ is the poison's macroscopic absorption coefficients.

From the definition of the reactivity in Eqn. 10, and Eqns. 11 and 12 we can readily get:

$$
\rho=-\frac{\Sigma_{a P}}{\Sigma_{a F}+\Sigma_{a M}}
$$

It is convenient to express the reactivity in an alternate form. For the unpoisoned critical core:

$$
1=k_{0}=\eta \varepsilon p f_{0}=\eta \varepsilon p \frac{\Sigma_{a F}}{\Sigma_{a F}+\Sigma_{a M}}
$$

From which:

$$
\Sigma_{a F}+\Sigma_{a M}=\eta \varepsilon p \Sigma_{a F}
$$

Substituting this value in the expression of the reactivity, and the expression for the regeneration factor, we get:

$$
\rho=-\frac{1}{\operatorname{vep}} \frac{\Sigma_{a P}}{\Sigma_{f}}
$$

For equilibrium xenon:

$$
\Sigma_{a P}=\sigma_{a X} X_{0}=\frac{\left(\gamma_{X}+\gamma_{I}\right) \Sigma_{f} \psi \sigma_{a X}}{\lambda_{X}+\sigma_{a X} \psi}
$$

Inserting the last equation for the expression for the reactivity we get:

$$
\rho=-\frac{\left(\gamma_{X}+\gamma_{I}\right) \psi \sigma_{a X}}{\left(\lambda_{x}+\sigma_{a X} \psi\right) v \varepsilon p}
$$

Dividing numerator and denominator by $\sigma_{a x}$ we get:

$$
\rho=-\frac{\left(\gamma_{X}+\gamma_{I}\right) \psi}{\left(\frac{\lambda_{x}}{\sigma_{a X}}+\psi\right) v \varepsilon p}
$$

The parameter:

$$
\varphi=\frac{\lambda_{X}}{\sigma_{a X}}=0.77 \times 10^{13}
$$

at 20 degrees $\mathrm{C}$, and has units of the flux [neutrons $\left./\left(\mathrm{cm}^{2} . \mathrm{sec}\right)\right]$. 
The expression for the reactivity is written in terms of $\varphi$ as:

$$
\rho=-\frac{\left(\gamma_{X}+\gamma_{I}\right) \psi}{(\varphi+\psi) \varepsilon p}
$$

For a reactor operating at high flux,

and we can write:

$$
\varphi \approx \psi
$$

$$
\rho=-\frac{\left(\gamma_{X}+\gamma_{I}\right)}{v \varepsilon p}
$$

\section{Example}

For a reactor fueled with $U^{235}, v=2.42, p=\varepsilon=1$, the value for $\rho$ for equilibrium xenon is:

$$
\rho=-\frac{(0.00237+0.06390)}{2.42}=-\frac{0.06627}{2.42}=-0.027384
$$

or a negative 2.74 percent.

\section{Reactor dead time}

A unique behavior occurs to the xenon after reactor shutdown. Although its production ceases, it continues to build up as a result of the decay of its iodine parent. Therefore the concentration of the xenon increases after shutdown. Since its cross section for neutrons is so high, it absorbs neutrons and prevents the reactor from being restarted for a period of time denoted as the "reactor dead time."

In a land based reactor, since the xenon eventually decays, after about 24 hours, the reactor can then be restarted. In naval propulsion applications, a naval vessel cannot be left in the water unable to be restarted and vulnerable to enemy attack by depth charges or torpedoes. For this reason, naval reactor cores must be provided with enough reactivity to overcome the xenon negative reactivity after shutdown.

To analyze the behavior, let us rewrite the rate equations for iodine and xenon with $\psi$ equal to 0 after shutdown:

$$
\begin{gathered}
\frac{d I(t)}{d t}=-\lambda_{I} I(t) \\
\frac{d X(t)}{d t}=+\lambda_{I} I(t)-\lambda_{X} X(t)
\end{gathered}
$$

Using Bateman's solution (Ragheb, 2011), the iodine and xenon concentrations become respectively:

$$
\begin{gathered}
I(t)=I_{0} e^{-\lambda_{I} t} \\
X(t)=X_{0} e^{-\lambda_{X} t}+\frac{\lambda_{I}}{\lambda_{I}-\lambda_{X}} I_{0}\left(e^{-\lambda_{X} t}-e^{-\lambda_{I} t}\right)
\end{gathered}
$$


Substituting for the equilibrium values of $\mathrm{X}_{0}$ and $\mathrm{I}_{0}$ we get:

$$
X(t)=\frac{\left(\gamma_{X}+\gamma_{I}\right) \Sigma_{f} \psi}{\lambda_{X}+\sigma_{a X} \psi} e^{-\lambda_{X} t}+\frac{\gamma_{I}}{\lambda_{I}-\lambda_{X}} \Sigma_{f} \psi\left(e^{-\lambda_{X} t}-e^{-\lambda_{I} t}\right)
$$

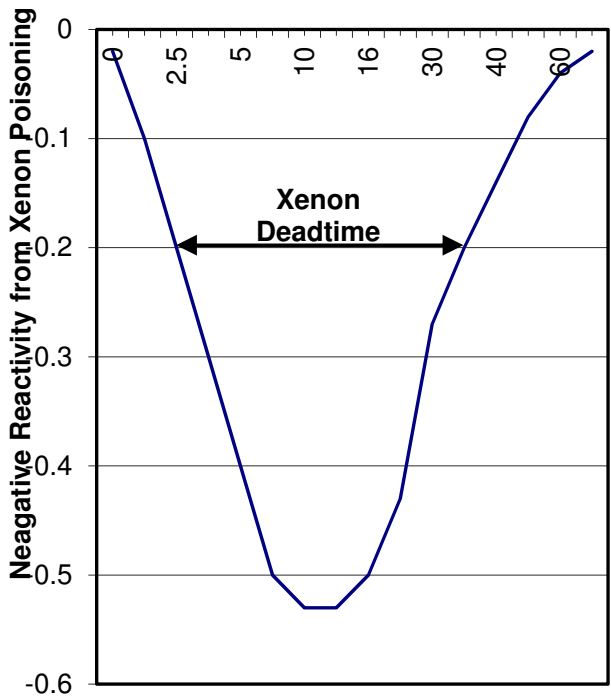

Time after Shutdown, [hours]

Fig. 7. Negative reactivity due to xenon poisoning. Flux $=5 \times 10^{14}\left[\mathrm{n} /\left(\mathrm{cm}^{2} . \mathrm{sec}\right)\right]$ (Ragheb, 2011).

The negative reactivity due to xenon poisoning is now a function of time and is given by:

$$
\begin{aligned}
\rho(t) & =-\frac{1}{v \varepsilon p} \frac{\Sigma_{a P(t)}}{\Sigma_{f}} \\
& =-\frac{1}{v \varepsilon p} \frac{\sigma_{a P} X(t)}{\Sigma_{f}} \\
& =-\frac{\sigma_{a P} \psi}{v \varepsilon p}\left[\frac{\gamma_{X}+\gamma_{I}}{\lambda_{X}+\sigma_{a X} \psi} e^{-\lambda_{X} t}+\frac{\gamma_{I}}{\lambda_{I}-\lambda_{X}}\left(e^{-\lambda_{X} t}-e^{-\lambda_{I} t}\right)\right]
\end{aligned}
$$

Figure 7 shows the negative reactivity resulting from xenon after reactor shutdown. It reaches a minimum value, which occurs at about 10 hours after shutdown. This post shutdown reactivity is important in reactors that have operated at a high flux level. If at any 
time after shutdown, the positive reactivity available by removing all the control rods is less than the negative reactivity caused by xenon, the reactor cannot be restarted until the xenon has decayed. In Fig. 7, at an assumed reactivity reserve of 20 percent, during the time interval from 2.5 hours to 35 hours, the reactor cannot be restarted. This period of $35-2.5=$ 32.5 hours is designated as the "Reactor Dead Time."

This reactor dead time is of paramount importance in mobile systems that may be prone to accidental scrams. This is more important at the end of core lifetime, when the excess reactivity is limited. For this reason, mobile reactors necessitate the adoption of special design features, providing the needed excess reactivity to override the negative xenon reactivity, such as the use of highly enriched cores.

In land based systems such as the Canadian Deuterium Uranium (CANDU) reactor concept, booster rods of highly enriched U235 are available to override the xenon dead time after shutdown, leading to a higher capacity factor. Power fluctuations induced to follow demand in any power reactor lead to xenon oscillations without any reactor shutdown. The changes of xenon concentrations due to load following are compensated for by adjusting the chemical shim or boron concentration in the coolant, and by control rods adjustments.

\section{Nuclear navies}

The USA nuclear fleet grew rapidly at the height of the East West Cold War in the 1980s. About one fourth of the submarine fleet carried intercontinental ballistic missiles. These can be ejected by the use of compressed air while the submarine is totally submerged, with the rocket engine starting once the missile is above the water surface.

In the Falkland Islands War, a single nuclear British submarine paralyzed the entire Argentinean Naval fleet. It sunk the cruiser "General Belgrano" and forced the Argentine Navy to not deploy out of port.

During the first and second Gulf Wars, and in the Lybia conflict, the USA Navy launched Tomahawk missiles, had unchallenged use of the oceans and protected 85 percent of the war supplies that were transported by ships.

\subsection{Navy carrier force}

The mission of the aircraft carrier force is to provide a credible, sustainable, independent forward presence and a conventional deterrence in peace times. In times of crisis, it operates as the cornerstone of joint and/or allied maritime expeditionary forces. It operates and support air attacks on enemies, protects friendly forces and engages in sustained independent operations in times of war. As an example, the vital statistics of the nuclear Nimitz Class aircraft carrier are:

Power Plant:

Length:

Beam:

Displacement:

Speed:

Aircraft:

Crew:
Two nuclear reactors, four shafts.

1,092 feet.

134 feet.

97,000 tons at full load.

30 knots, 34.5 miles per hour.

85.

500 officers, 5,000 enlisted. 


\subsection{Nuclear submarine force}

The USA submarine force maintains its position as the world's preeminent submarine force. It incorporates new and innovative technologies allowing it to maintain dominance throughout the naval battle space. It incorporates the multiple capabilities of submarines and develops tactics for high seas control, land battle support as well as strategic deterrence. It also fills the role of a stealthy signal and intelligence gathering and a full spectrum of special operations and expeditionary missions. It includes forces of ballistic missiles submarines (SSBN), guided missile submarines (SSGN), and attack submarines (SSN). The vital statistics of the Ballistic Missile Trident submarines and the guided missiles submarines are:

Armament, SSBN:

Armament, SSGN:

Power Plant:

Length:

Beam:

Displacement:

Speed:

Crew:
Trident missiles.

154 Tomahawk missiles, 66 Special operation Forces.

One nuclear reactor, one shaft.

560 feet.

42 feet.

18,750 tons, submerged.

20 knots, 23 miles per hour.

15 officers, 140 enlisted.

The statistics for the fast attack Los Angeles class submarines are:

Power Plant: One nuclear reactor, one shaft.

Length: $\quad 360$ feet.

Beam: 33 feet.

Displacement: $\quad 6,900$ tons, submerged.

Speed: $\quad 25$ knots, 28 miles per hour.

Crew: $\quad 12$ officers, 121 enlisted.

\subsection{Russian navy}

The nuclear Russian navy also reached its peak at the same time as the USA navy. The first of the Typhoon Class 25,000 ton strategic ballistic missile submarines was launched in 1980 from the Severodvinsk Shipyard on the White Sea. In the same year the first Oscar Class guided missile submarine was launched. It is capable of firing 24 long range anti-ship cruise missiles while remaining submerged. Five shipyards produced seven different classes of submarines.

The Delta IV class is nuclear-powered with two VM-4 pressurized water reactors rated at $180 \mathrm{MWth}$. There are two turbines, type GT3A-365 rated at 27.5MW. The propulsion system drives two shafts with seven-bladed fixed-pitch propellers.

\subsection{Chinese navy}

Five hundred years ago the contender for the dominance of the world's oceans was the Chinese imperial exploration fleet which was at its peak technologically centuries ahead of its competitors. A strategic mistake by its emperor was to neglect its sea access with the result of opening the door to European (The Opium Wars) and then Japanese military intervention and occupation. Being the world's second largest importer of petroleum after the USA, China seeks to protect its energy corridors by sea and free access to Southeast Asia sea lanes beyond the Indochinese Peninsula. 
China's naval fleet as of 2008 had 5 nuclear powered fast attack submarines and one ballistic missiles submarine carrying 12-16 nuclear tipped missiles with a range of 3,500 km. This is in addition to 30 diesel electric submarines with 20 other submersibles.

The Chinese submarine fleet is expected to exceed the number of USA's Seventh Fleet ships in the Pacific Ocean by 2020 with the historic patience and ambition to pursue a long term strategy of eventually matching and then surpassing the USA's regional dominance.

\section{Nuclear cruise missile submarines}

The nuclear powered Echo I and II, and the Charlie I and II can fire eight antiship weapons cruise missiles while remaining submerged at a range of up to 100 kilometers from the intended target. These cruise missile submarines also carry ASW and anti-ship torpedoes.

The nuclear cruise missile submarines are meant to operate within range of air bases on land. Both forces can then launch coordinated attacks against an opponent's naval forces. Reconnaissance aircraft can then provide target data for submarine launched missiles.

\section{Nuclear ballistic missile submarines}

Submarine Launched Ballistic Missiles (SLBMs) on Nuclear Powered Ballistic Missile Submarines (SSBNs) have been the basis of strategic nuclear forces. Russia had more land based Intercontinental Ballistic Missiles (ICBMs) than the SLBM forces (Weinberger, 1981). The Russian ICBM and SLBM deployment programs initially centered on the SS-9 and SS-11 ICBMs and the SS-N-6/Yankee SLBM/SSBN weapons systems. They later used the Multiple Independently targetable Reentry Vehicles (MIRVs) SS-N-18 on the Delta Class nuclear submarines, and the SS-NX-20 on the nuclear Typoon Class SSBN submarine.

The Russian SLBM force has reached 62 submarines carrying 950 SLBMs with a total of almost 2,000 nuclear warhead reentry vehicles. Russia deployed 30 nuclear SSBNs, and the 20 tube very large Typhoon SSBN in the 1980s. These submarines were capable to hit targets across the globe from their homeports.

The 34 deployed Yankee Class nuclear submarines each carried 16 nuclear tipped missiles. The SS-N-6/Yankee I weapon system is composed of the liquid propellant SS-N-6 missile in 16 missile tubes launchers on each submarine. One version of the missiles carries a single Reentry Vehicle (RV) and has an operational range of about 2,400 to 3,000 kilometers. Another version carries $2 \mathrm{RVs}$, and has an operational range of about 3,000 kilometers.

The Delta I and II classes of submarines displaced 11,000 tons submerged and have an overall length of about 140 meters. These used the SS-N-8 long range, two stages, liquid propellant on the 12-missile tube Delta I and the 16 missile tube Delta II submarines. The SS$\mathrm{N}-8$ has a range of about 9,000 kilometers and carries one RV. The SS-N-18 was used on the 16 missile tube Delta III submarines, and has MIRV capability with a booster range of 6,500 to 8,000 kilometers, depending on the payload configuration. The Delta III nuclear submarines could cover most of the globe from the relative security of their home waters with a range of 7,500 kilometers.

The Typhoon Class at a 25,000 tons displacement, twice the size of the Delta III with a length of $170 \mathrm{~m}$ and 20 tubes carrying the SS-NX-20 missile each with $12 \mathrm{RVs}$, has even greater range at $8,300 \mathrm{kms}$, higher payload, better accuracy and more warheads. 


\section{Nuclear attack submarines}

At some time the Russian Navy operated about 377 submarines, including 180 nuclear powered ones, compared with 115 in the USA navy. The Russian navy operated 220 attack submarines, 60 of them were nuclear powered. These included designs of the November, Echo, Victor, and Alfa classes. The Victor class attack submarine, was characterized by a deep diving capability and high speed.

\section{Alfa class submarines}

The Alfa Class submarine is reported to have been the fastest submarine in service in any navy. It was a deep diving, titanium hull submarine with a submerged speed estimated to be over 40 knots. The titanium hull provided strength for deep diving. It also offered a reduced weight advantage leading to higher power to weight ratios resulting in higher accelerations. The higher speed could also be related to some unique propulsion system. The high speeds of Russian attack submarines were meant to counter the advanced propeller cavitation and pump vibration reduction technologies in the USA designs, providing them with silent and stealth hiding and maneuvering.

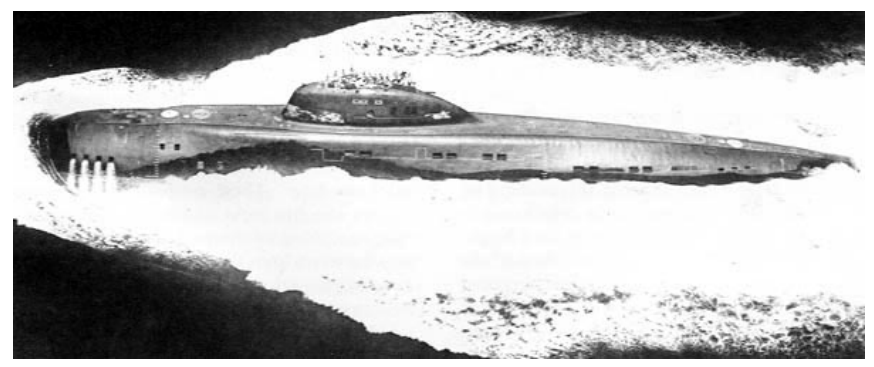

Fig. 8. The Nuclear Powered Russian VICTOR I class Attack Submarine (Weinberger, 1981).

The Alfa Class of Russian submarines used a lead and bismuth alloy cooled fast reactors. They suffered corrosion on the reactor components and activation through the formation of the highly toxic $\mathrm{Po}^{210}$ isotope. Refueling needed a steam supply to keep the liquid metal molten above $257 \mathrm{oF}$.

Advantages were a high cycle efficiency and that the core can be allowed to cool into a solid mass with the lead providing adequate radiation shielding. This class of submarines has been decommissioned.

\section{Seawolf class submarines}

The Seawolf class of submarines provided stealth, endurance and agility and are the most heavily armed fast attack submarines in the world.

They provided the USA Navy with undersea weapons platforms that could operate in any scenario against any threat, with mission and growth capabilities that far exceed Los Angeles-class submarines. The robust design of the Seawolf class enabled these submarines to perform a wide spectrum of military assignments, from underneath the Arctic icepack to littoral regions of the world. These were capable of entering and remaining in the backyards of potential adversaries undetected, preparing and shaping the battle space and striking 
rapidly. Their missions include surveillance, intelligence collection, special warfare, cruise missile strike, mine warfare, and anti-submarine and anti-surface ship warfare

\begin{tabular}{|l|l|}
\hline Builder & General Dynamics, Electric Boat Division. \\
\hline Power plant & One S6W nuclear reactor, one shaft. \\
\hline Length & $\begin{array}{l}\text { SSN 21 and SSN 22: 353 feet (107.6 meters) } \\
\text { SSN 23: 453 feet (138 meters) }\end{array}$ \\
\hline Beam & 40 feet (12.2 meters) \\
\hline Submerged Displacement & $\begin{array}{l}\text { SSN 21 and SSN 22: 9,138 tons (9,284 metric tons) } \\
\text { SSN 23 12,158 tons (12,353 metric tons) }\end{array}$ \\
\hline Speed & 25+ knots (28+ miles / hour, 46.3+ kilometers / hour) \\
\hline Crew & 140: 14 Officers; 126 Enlisted \\
\hline Armaments & Tomahawk missiles, MK-48 torpedoes, eight torpedo tubes \\
\hline Commissioning dates & $\begin{array}{l}\text { Seawolf: July 19, 1997 } \\
\text { Connecticut: December11, 1998; } \\
\text { Jimmy Carter: February 19, 2005. }\end{array}$ \\
\hline
\end{tabular}

Table 5. Seawolf class of submarines technical specifications.

\section{Ohio class submarines}

The Ohio Class submarine is equipped with the Trident strategic ballistic missile from Lockheed Martin Missiles and Space. The Trident was built in two versions, Trident I (C4), which is phased out, and the larger and longer range Trident II (D5), which entered service in 1990. The first eight submarines, (SSBN 726 to 733 inclusive) were equipped with Trident I and the following ten (SSBN 734 to 743) carry the Trident II. Conversion of the four Trident I submarines remaining after the START II Treaty (Henry M. Jackson, Alabama, Alaska and Nevada), to Trident II began in 2000 and completed in 2008. Lockheed Martin produced 12 Trident II missiles for the four submarines.

The submarine has the capacity for 24 Trident missile tubes in two rows of 12 . The dimensions of the Trident II missile are length $1,360 \mathrm{~cm} \times$ diameter $210 \mathrm{~cm}$ and the weight is $59,000 \mathrm{~kg}$. The three-stage solid fuel rocket motor is built by ATK (Alliant Techsystems) Thiokol Propulsion. The USA Navy gives the range as "greater than $7,360 \mathrm{~km}$ " but this could be up to $12,000 \mathrm{~km}$ depending on the payload mix. Missile guidance is provided by an inertial navigation system, supported by stellar navigation. Trident II is capable of carrying up to twelve MIRVs, each with a yield of 100 kilotons, although the SALT treaty limits this number to eight per missile. The circle of equal probability, or the radius of the circle within which half the strikes will impact, is less than $150 \mathrm{~m}$. The Sperry Univac Mark 98 missile control system controls the 24 missiles.

The Ohio class submarine is fitted with four $533 \mathrm{~mm}$ torpedo tubes with a Mark 118 digital torpedo fire control system. The torpedoes are the Gould Mark 48 torpedoes. The Mark 48 is a heavy weight torpedo with a warhead of $290 \mathrm{~kg}$, which has been operational in the USA Navy since 1972. The torpedo can be operated with or without wire guidance and the system has active and/or passive acoustic homing. The range is up to $50 \mathrm{~km}$ at a speed of 40 knots. After launch, the torpedo carries out target search, acquisition and attack procedures delivering to a depth of 3,000 ft.

The Ohio class submarine is equipped with eight launchers for the Mk 2 torpedo decoy. Electronic warfare equipment is the WLR-10 threat warning system and the WLR-8(V) 
surveillance receiver from GTE of Massachusetts. The WLR-8(V) uses seven YIG tuned and vector tuned super heterodyne receivers to operate from $50 \mathrm{MHz}$ up to J-band. An acoustic interception and countermeasures system, AN/WLY-1 from Northrop Grumman, has been developed to provide the submarine with an automatic response against torpedo attack.

The surface search, navigation and fire control radar is BPS $15 \mathrm{~A} \mathrm{I} / \mathrm{J}$ band radar. The sonar suite includes: IBM BQQ 6 passive search sonar, Raytheon BQS 13, BQS 15 active and passive high-frequency sonar, $\mathrm{BQR} 15$ passive towed array from Western Electric, and the active BQR 19 navigation sonar from Raytheon. Kollmorgen Type 152 and Type 82 periscopes are fitted.

The main machinery is the GE PWR S8G reactor system with two turbines providing 60,000 $\mathrm{hp}$ and driving a single shaft. The submarine is equipped with a $325 \mathrm{hp}$ Magnatek auxiliary propulsion motor. The propulsion provides a speed in excess of 18 knots surfaced and 25 knots submerged.

It is designed for mine avoidance, special operations forces delivery and recovery. It uses non acoustic sensors, advanced tactical communications and non acoustic stealth. It is equipped with conformal sonar arrays which seek to provide an optimally sensor coated submarine with improved stealth at a lower total ownership cost. New technology called Conformal Acoustic Velocity Sonar (CAVES) could replace the existing Wide Aperture Array technology and is to be implemented in units of the Virginia Class.

\begin{tabular}{|l|l|}
\hline Power Plant & $\begin{array}{l}\text { Single S9G PWR } \\
\text { Single shaft with pump jet propulsion } \\
\text { One secondary propulsion submerged motor }\end{array}$ \\
\hline Displacement & 7,800 tons, submerged \\
\hline Length & $277 \mathrm{ft}$ \\
\hline Draft & $32 \mathrm{ft}$ \\
\hline Beam & $34 \mathrm{ft}$ \\
\hline Speed & $25+$ knots, submerged \\
\hline Horizontal tubes & Four 21 inches torpedo tubes \\
\hline Vertical tubes & 12 Vertical Launch System Tubes \\
\hline Weapon systems & $\begin{array}{l}39, \text { including: } \\
\text { Vertical Launch System Tomahawk Cruise Missiles } \\
\text { Mk 48 ADCAP Heavy weight torpedoes } \\
\text { Advanced Mobile Mines } \\
\text { Unmanned Undersea Vehicles }\end{array}$ \\
\hline Special warfare & Dry Deck Shelter \\
\hline Sonars & $\begin{array}{l}\text { Spherical active/passive arrays } \\
\text { Light Weight Wide Aperture Arrays } \\
\text { TB-16, TB-29 and future towed arrays } \\
\text { High frequency chin and sail arrays }\end{array}$ \\
\hline Counter measures & $\begin{array}{l}1 \text { internal launcher } \\
14 \text { external launchers }\end{array}$ \\
\hline Crew & 113 officers and men \\
\hline
\end{tabular}

Table 6. Technical Specifications of the Virginia Class of Submarines. 
High Frequency Sonar will play a more important role in future submarine missions as operations in the littorals require detailed information about the undersea environment to support missions requiring high quality bathymetry, precision navigation, mine detection or ice avoidance. Advanced High Frequency Sonar systems are under development and testing that will provide submarines unparalleled information about the undersea environment. This technology will be expanded to allow conformal sonar arrays on other parts of the ship that will create new opportunities for use of bow and sail structure volumes while improving sonar sensor performance.

\section{Nuclear ice-breakers}

Nuclear-powered icebreakers were constructed by Russia for the purpose of increasing the shipping along the northern coast of Siberia, in ocean waters covered by ice for long periods of time and river shipping lanes. The nuclear powered icebreakers have far more power than their diesel powered counterparts, and for extended time periods. During the winter, the ice along the northern Russian sea way varies in thickness from 1.2 - 2 meters. The ice in the central parts of the Polar Sea is 2.5 meters thick on average. Nuclear-powered icebreakers can break this ice at speeds up to 10 knots. In ice free waters the maximum speed of the nuclear powered icebreakers is 21 knots. In 1988 the NS Sevmorpu was commissioned in Russia to serve the northern Siberian ports. It is a 61,900 metric tonnes, 260 $\mathrm{m}$ long and is powered by the KLT-40 reactor design, delivering 32.5 propeller MW from the 135 MWth reactor.

Russia operated at some time up to eight nuclear powered civilian vessels divided into seven icebreakers and one nuclear-powered container ship. These made up the world's largest civilian fleet of nuclear-powered ships. The vessels were operated by Murmansk Shipping Company (MSC), but were owned by the Russian state. The servicing base Atomflot is situated near Murmansk, $2 \mathrm{~km}$ north of the Rosta district.

Icebreakers facilitated ores transportation from Norilsk in Siberia to the nickel foundries on the Kola Peninsula, a journey of about 3,000 kms. Since 1989 the nuclear icebreakers have been used to transport wealthy Western tourists to visit the North Pole. A three week long trip costs $\$ 25,000$.

The icebreaker Lenin, launched in 1957 was the world's first civilian vessel to be propelled by nuclear power. It was commissioned in 1959 and retired from service in 1989. Eight other civilian nuclear-powered vessels were built: five of the Arktika class, two river icebreakers and one container ship. The nuclear icebreaker Yamal, commissioned in 1993, is the most recent nuclear-powered vessel added to the fleet.

The nuclear icebreakers are powered by PWRs of the KLT-40 type. The reactor contains fuel enriched to 30-40 percent in $\mathrm{U}^{235}$. By comparison, nuclear power plants use fuel enriched to only 3-5 percent. Weapons grade uranium is enriched to over 90 percent. American submarine reactors are reported to use up to 97.3 percent enriched $U^{235}$. The irradiated fuel in test reactors contains about 32 percent of the original $U^{235}$, implying a discharge enrichment of $97.3 \times 0.32=31.13$ percent enrichment.

Under normal operating conditions, the nuclear icebreakers are only refueled every three to four years. These refueling operations are carried out at the Atomflot service base. Replacement of fuel assemblies takes approximately $11 / 2$ months.

For each of the reactor cores in the nuclear icebreakers, there are four steam generators that supply the turbines with steam. The third cooling circuit contains sea water that condenses 
and cools down the steam after it has run through the turbines. The icebreaker reactors' cooling system is especially designed for low temperature Arctic sea water.

\section{Discussion: Defining trends}

Several trends may end up shaping the future of naval ship technology: the all electrical ship, stealth technology, littoral vessels and moored barges for power production. Missions of new naval systems are evolving towards signal intelligence gathering and clandestine special forces insertion behind enemy lines requiring newer designs incorporating stealth configurations and operation.

The all-electric ship propulsion concept was adopted for the future surface combatant power source. This next evolution or Advanced Electrical Power Systems (AEPS) involves the conversion of virtually all shipboard systems to electric power; even the most demanding systems, such as propulsion and catapults aboard aircraft carriers. It would encompass new weapon systems such as modern electromagnetic rail-guns and free electron lasers.

Littoral vessels are designed to operate closer to the coastlines than existing vessels such as cruisers and destroyers. Their mission would be signal intelligence gathering, stealth insertion of Special Forces, mine clearance, submarine hunting and humanitarian relief. Unmanned Underwater Vehicles (UUVs), monitored by nuclear-powered Virginia Class submarines would use Continuous Active Sonar (CAS) arrays which release a steady stream of energy, the sonar equivalent of a flashlight would be used as robots to protect carrier groups and turning attacking or ambushing submarines from being the hunters into being the hunted.

\subsection{All electric propulsion and stealth ships}

The CVN-21's new nuclear reactor not only will provide three times the electrical output of current carrier power plants, but also will use its integrated power system to run an Electro Magnetic Aircraft Launch System (EMALS) to replace the current steam-driven catapults, combined with an Electromagnetic Aircraft Recovery System (EARS). To store large amounts of energy, flywheels, large capacitor banks or other energy storage systems would have to be used.

A typical ship building experience involved the design conversion of one class of submarines to an all-electric design. The electric drive reduced the propulsion drive system size and weight; eliminating the mechanical gearbox. However, the power system required extensive harmonic filtering to eliminate harmonic distortion with the consequence that the overall vessel design length increased by 10 feet.

Tests have been conducted to build stealth surface ships based on the technology developed for the F-117 Nighthawk stealth fighter. The first such system was built by the USA Navy as "The Sea Shadow." The threat from ballistic anti ship missiles and the potential of nuclear tipped missiles has slowed down the development of stealth surface ships. The USA Navy cut its $\$ 5$ billion each DDG-1000 stealth destroyer ships from an initially planned seven to two units.

Missile defense emerged as a major naval mission at the same time that the DDG-1000's stealth destroyer design limitations and rising costs converged, all while shipbuilding 
budgets were getting squeezed. The SM-3 Standard missile, fired only by warships, is the most successful naval missile defense system; having passed several important trials while other Ballistic Missile Defense, BMD weapons are under testing. The ballistic-missile threat is such that the USA Navy decided it needed 89 ships capable of firing the SM-3 and that the DDG-1000 realistically would never be able to fire and guide the SM-3 since the stealth destroyer is optimized for firing land-attack missiles not Standard missiles.

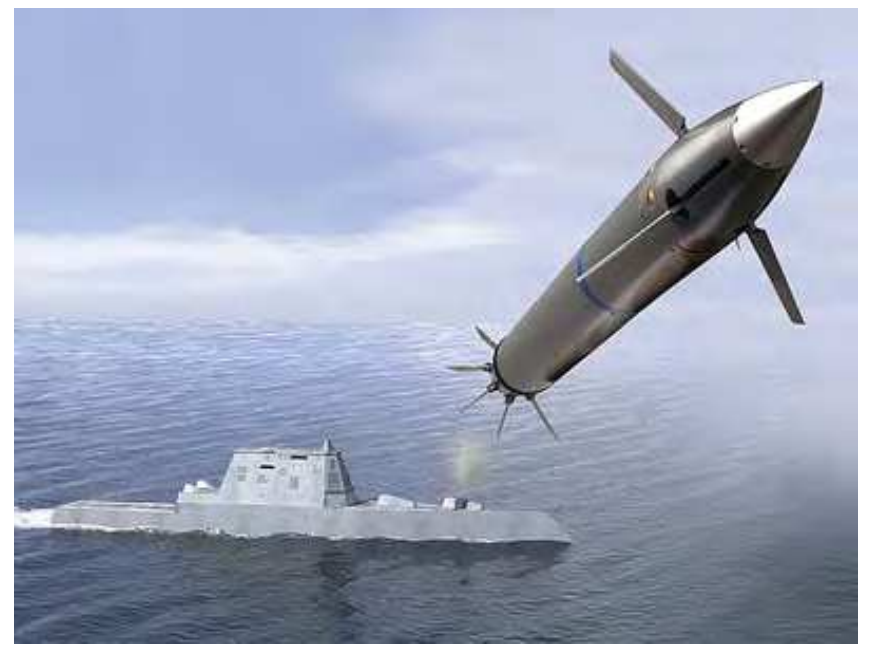

Fig. 9. The DDG-1000 stealth destroyer is optimized for firing land-attack missiles; not Ballistic Missile Defense, BMD missiles. The Raytheon Company builds the DDG-1000's SPY-3 radar, and Bath Iron Works, the Maine shipyard builds the DDG-1000. (Source: Raytheon).

The USA Navy has 84 large surface combatants, split between Arleigh-Burke Class destroyers and the Ticonderoga Class cruisers, capable of carrying the combination of Standard missiles and the BMD capable Aegis radar. The DDG-1000 cannot affordably be modified to fire SM-3s. So the Navy needs another 12 SM-3 "shooters" to meet the requirement for missile defense, and there was no time to wait for the future CG-X cruiser. With new amphibious ships, submarines, carriers and Littoral Combat Ships in production alongside the DDG-1000s, there was no room in the budget for five extra DDG-1000s.

\subsection{Multipurpose floating barges}

The vision of floating barges with nuclear reactors to produce electrical power for industrial and municipal use, hydrogen for fuel cells, as well as fresh desalinated water at the shores of arid areas of the world may become promising future prospects. The electricity can be used to power a new generation of transportation vehicles equipped with storage batteries, or the hydrogen can be used in fuel cells vehicles. An urban legend is related about a USA Navy nuclear submarine under maintenance at Groton, Connecticut, temporarily supplying the neighboring port facilities with electricity when an unexpected power outage occurred. This would have required the conversion, of the 120 Volts and $400 \mathrm{~Hz}$ military electricity standard to the $10-12 \mathrm{kV}$ and $60 \mathrm{~Hz}$ civilian one. Submarines tied up at port connect to a 
connection network that matches frequency and voltage so that the reactors can be shut down. The two electrical generators on a typical submarine would provide about 3 MWe $\times 2$ $=6 \mathrm{MWe}$ of power, with some of this power used by the submarine itself. In case of a loss of local power, docked vessels have to start their reactors or their emergency diesel generators anyway.

The accumulated experience of naval reactors designs is being as the basis of a trend toward the consideration of a new generation of modular compact land-based reactor designs.

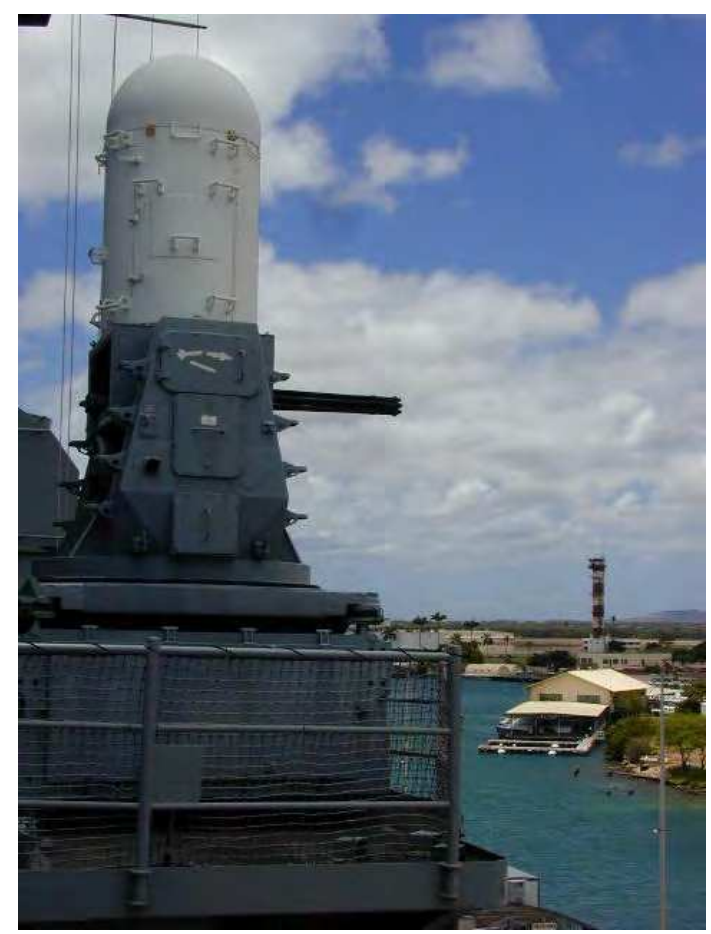

Fig. 10. The Phalanx radar-guided gun, nicknamed as R2-D2 from the Star-Wars movies, is used for close-in ship defense. The radar controlled Gatling gun turret shooting tungsten armor-piercing, explosive, or possibly depleted uranium munitions on the USS Missouri, Pearl Harbor, Hawaii. (Photo: M. Ragheb).

\section{References}

Ragheb, Magdi, "Lecture Notes on Fission Reactors Design Theory," FSL-33, University of Illinois, 1982.

Lamarsh, John, "Introduction to Nuclear Engineering," Addison-Wesley Publishing Company, 1983.

Murray, Raymond L., "Nuclear Energy," Pergamon Press, 1988.

Collier, John G., and Geoffrey F. Hewitt, "Introduction to Nuclear Power," Hemisphere Publishing Corp., Springer Verlag, 1987. 
Broder, K. K. Popkov, and S. M. Rubanov, "Biological Shielding of Maritime Reactors," AECtr-7097, UC-41,TT-70-5006, 1970.

Weinberger, Caspar, "Soviet Military Power," USA Department of Defense, US Government Printing Office, 1981.

Reid, T. R., “The Big E,” National Geographic, January 2002.

Poston, David I. , "Nuclear design of the SAFE-400 space fission reactor," Nuclear News, p.28, Dec. 2002.

Reistad, Ole, and Povl L Olgaard, "Russian Power Plants for Marine Applications," NKS138, Nordisk Kernesikkerhedsforskning, April 2006.

Ragheb, Magdi, "Nuclear, Plasma and Radiation Science, Inventing the Future," https://netfiles.uiuc.edu/mragheb/www, 2011. 


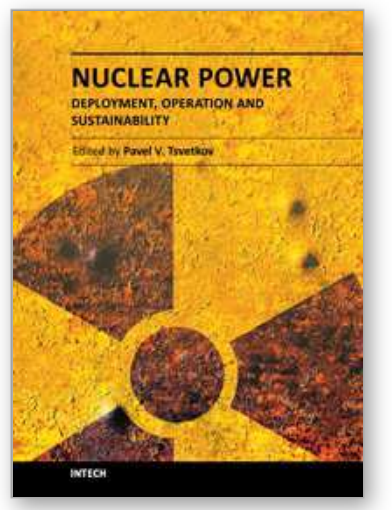

\author{
Nuclear Power - Deployment, Operation and Sustainability \\ Edited by Dr. Pavel Tsvetkov
}

ISBN 978-953-307-474-0

Hard cover, 510 pages

Publisher InTech

Published online 09, September, 2011

Published in print edition September, 2011

We are fortunate to live in incredibly exciting and incredibly challenging time. Energy demands due to economic growth and increasing population must be satisfied in a sustainable manner assuring inherent safety, efficiency and no or minimized environmental impact. These considerations are among the reasons that lead to serious interest in deploying nuclear power as a sustainable energy source. At the same time, catastrophic earthquake and tsunami events in Japan resulted in the nuclear accident that forced us to rethink our approach to nuclear safety, design requirements and facilitated growing interests in advanced nuclear energy systems. This book is one in a series of books on nuclear power published by InTech. It consists of six major sections housing twenty chapters on topics from the key subject areas pertinent to successful development, deployment and operation of nuclear power systems worldwide. The book targets everyone as its potential readership groups - students, researchers and practitioners - who are interested to learn about nuclear power.

\title{
How to reference
}

In order to correctly reference this scholarly work, feel free to copy and paste the following:

Magdi Ragheb (2011). Nuclear Naval Propulsion, Nuclear Power - Deployment, Operation and Sustainability, Dr. Pavel Tsvetkov (Ed.), ISBN: 978-953-307-474-0, InTech, Available from:

http://www.intechopen.com/books/nuclear-power-deployment-operation-and-sustainability/nuclear-navalpropulsion

\section{INTECH}

open science | open minds

\section{InTech Europe}

University Campus STeP Ri

Slavka Krautzeka 83/A

51000 Rijeka, Croatia

Phone: +385 (51) 770447

Fax: +385 (51) 686166

www.intechopen.com

\section{InTech China}

Unit 405, Office Block, Hotel Equatorial Shanghai

No.65, Yan An Road (West), Shanghai, 200040, China

中国上海市延安西路65号上海国际贵都大饭店办公楼 405 单元

Phone: +86-21-62489820

Fax: $+86-21-62489821$ 
(C) 2011 The Author(s). Licensee IntechOpen. This chapter is distributed under the terms of the Creative Commons Attribution-NonCommercialShareAlike-3.0 License, which permits use, distribution and reproduction for non-commercial purposes, provided the original is properly cited and derivative works building on this content are distributed under the same license. 